\title{
Aktivitas Antibakteri Ekstrak Batang Kecombrang (Etlingera elatior (Jack) R.M.Sm.) Terhadap Bakteri Plak Gigi Streptococcus mutans
}

\section{Antibacterial Activity of Kecombrang Rod Extract (Etlingera elatior (Jack) R.M.Sm.) on Dental Plaque Bacteria Streptococcus mutans}

\author{
Nani Suryani ${ }^{1}{ }^{*}$, Devi Nurjanah $^{2}$, dan Dimas Danang Indriatmoko ${ }^{2}$ \\ ${ }^{1}$ Departemen Kimia, Fakultas Sains dan Farmasi Universitas Mathla'ul Anwar Banten Jl. Raya Labuan \\ km.23, Cikaliung, Saketi. Pandeglang. Banten. 42273 \\ ${ }^{2}$ Departemen Farmasi, Fakultas Sains dan Farmasi Universitas Mathla'ul Anwar Banten. Jl. Raya \\ Labuan km.23, Cikaliung, Saketi. Pandeglang. Banten. 42273 \\ *Email: nanisuryani7688@gmail.com
}

DOI: https://doi.org/10.26874/jkk.v2i1.19

Received: 1 April 2019, Revised: 13 Mei 2019, Accepted: 21 Mei 2019, Online: 31 Mei 2019

\begin{abstract}
Abstrak
Plak gigi terbentuk oleh biofilm yang menutupi permukaan gigi. Biofilm merupakan lapisan lendir yang terdiri dari jutaan sel bakteri, saliva dan sisa makanan. Ketika pembentukan biofilm tidak terkendali, maka akan dengan mudah menebal di permukaan gigi yang disebut dengan plak. Biofilm ini merupakan tempat yang baik untuk kolonisasi dan pertumbuhan berbagai jenis bakteri salah satunya adalah bakteri Streptococcus mutans. Bakteri S. mutans dapat membentuk koloni yang melekat erat pada permukaan gigi dan merupakan bakteri kariogenik yang mampu memfermentasikan sukrosa (karbohidrat) menjadi asam, menurunkan $\mathrm{pH}$ permukaan gigi dan menyebabkan mineralisasi gigi. Sehingga untuk pengendalian bakteri tersebut digunakan sediaan yang mengandung antibakteri, salah satunya dari bahan alam yaitu kecombrang. Penelitian ini bertujuan mengetahui aktivitas antibakteri dari ekstrak batang Etlingera elatior yang diekstraksi oleh pelarut berdasarkan perbedaan tingkat kepolaran. Pengujian aktivitas antibakteri ekstrak dibagi menjadi 5 kelompok yaitu untuk ekstrak $n$-heksana, etil asetat, etanol 20, 40, 60 dan 80\%, kontrol positif minosep dan kontrol negatif (DMSO). Hasil skrining fitokimia menunjukkan bahwa tanaman E. elatior mengandung metabolit sekunder flavonoid, tanin, saponin, triterpenoid dan alkaloid. Ekstrak etil asetat memiliki aktivitas antibakteri kategori kuat terhadap $S$. mutans sebesar 17,22; 17,55; 17,77 dan 18,55 mm, lebih tinggi dibandingkan dari kontrol positif minosep yang memiliki aktivitas antibakteri sebesar $16,55 \mathrm{~mm}$.
\end{abstract}

Kata kunci: Etlingera elatior (Jack) R.M.Sm.), Sterpotococcus mutans, Plak gigi, antibakteri

\begin{abstract}
Dental plaques are formed by biofilms that cover the surface of the tooth. Biofilm is a mucous layer consisting of millions of bacterial cells, saliva and food scraps. When biofilm formation is out of control, it will easily thicken on the tooth surface called plaque. This biofilm is a good place for colonization and growth of various types of bacteria, one of which is the Sterpotococcus mutans bacteria. S. mutans bacteria can form colonies that are firmly attached to the tooth surface and are cariogenic bacteria that are able to ferment sucrose (carbohydrates) into acid, reduce the $\mathrm{pH}$ of the tooth surface and cause tooth mineralization. So for the control of these bacteria, preparations containing antibacterials are used, one of which is natural ingredients, namely Kecombrang. The aim of this study was to determine the antibacterial activity of the Etlingera elatior (Jack) R.M.Sm. stem extract extracted by solvent based on the level of polarity. Antibacterial activity testing of extracts was divided into 5 groups, namely for n-hexane, ethyl acetate, ethanol extract 20,40,60 and 80\%, positive control of minosep and negative control (DMSO). The test results showed that E. elatior (Jack) RMSm.) contained secondary metabolites
\end{abstract}


of flavonoids, tannins, saponins, triterpenoids and alkaloids, ethyl acetate extracts with concentrations of 20,40, 60 and $80 \%$, having strong antibacterial activity against $S$. mutans of 17.22; 17,55; 17.77 and $18.55 \mathrm{~mm}$, higher than the positive control of Minosep which has antibacterial activity of $16.55 \mathrm{~mm}$.

\section{Keywords: antibacterial, dental plaque, Etlingera elatior (Jack) R.M.Sm.), Sterpotococcus mutans}

\section{Pendahuluan}

Dental plak terbentuk oleh biofilm yang menutupi permukaan gigi. Biofilm merupakan lapisan lendir yang terdiri dari jutaan sel bakteri, saliva dan sisa makanan. Ketika pembentukan biofilm tidak terkendali, maka akan dengan mudah menebal di permukaan gigi yang disebut dengan plak. Biofilm ini merupakan tempat yang baik untuk kolonisasi dan pertumbuhan berbagai jenis bakteri [1]. Bakteri S. mutans dapat membentuk koloni yang melekat erat pada permukaan gigi dan merupakan bakteri kariogenik yang mampu memfermentasikan sukrosa (karbohidrat) menjadi asam, menurunkan $\mathrm{pH}$ permukaan gigi dan menyebabkan mineralisasi gigi [2]. Bakteri S. mutans disebut juga mikroorganisme kariogenik karena kemampuannya memecah gula untuk dijadikan energi dan menghasilkan lingkungan asam, yang dapat mendemineralisasi struktur gigi. Hasilnya lapisan gigi menjadi hancur [3].

Salah satu cara untuk mengatasi terbentuknya plak gigi yaitu dengan menggunakan obat kumur yang mengandung bahan antibakteri. Tanaman kecombrang atau dikenal dengan nama Etlingera. elatior (Jack) R.M.Sm merupakan salah satu jenis rempahrempah yang sejak lama dikenal dan dimanfaatkan oleh manusia sebagai obat-obatan berkaitan dengan khasiatnya, yaitu sebagai penghilang bau badan dan bau mulut. Bagian yang biasa digunakan dari tanaman ini adalah bunga, daun dan batangnya [4]. Tanaman E. elatior merupakan salah satu tanaman yang memiliki efek antimikroba. Ekstrak etanol daun E. elatior dilaporkan dapat menghambat pertumbuhan beberapa mikroba di antaranya adalah Eschercia coli, Bacillus subtilis, Staphylococcus aureus, Streptococcus mutans dan Pseudomonas aeruginosa [5].

Batang E. elatior memiliki potensi sebagai antibakteri, ditunjukkan dengan adanya kandungan minyak esensial sebesar $0,0029 \%$ dan kandungan flavonoid pada batangnya. Bagian batang yang sering digunakan oleh masyarakat adalah batang bagian dalam. Hal ini disebabkan karena pada bagian dalam lebih banyak mengandung flavonoid dari pada bagian luar batangnya. Bagian dalam batang E. elatior yang mengandung alkaloid, saponin, fenolik, flavonoid, triterpenoid, steroid, dan glikosida dapat berfungsi sebagai antimikroba [6]. Bunganya digunakan juga sebagai bahan pembuatan sabun, sampo dan parfum. Sedangkan daunnya yang dikombinasikan dengan tanaman aromatik lain dimanfaatkan sebagai penghilang bau badan [7].

Batang E. elatior mengandung 1-dodekanol, 1-tetradekena, dan 5-(3-metil-but-1-enoiloksi)benzena-1,2,4-triol [8], ergosterol 5,8- peroksida, sitostenon, isokuersetrin, kaemferol 3 glukoronida, katekin dan demetoksikurkumin [9].

Penelitian ini bertujuan untuk mengetahui aktivitas antibakteri ekstrak batang E. elatior yang difraksinasi terhadap bakteri $S$. mutans sehingga bisa menjadi acuan penelitian selanjutnya untuk diformulasikan sebagai obat kumur.

\section{Metode}

\subsection{Alat dan Bahan Penelitian}

$\underline{\text { Alat Penelitian }}$

Peralatan yang digunakan dalam penelitian ini adalah alat-alat gelas laboratorium, blender, neraca analitik, kertas label, rotary evaporator, kertas saring whatman, autoklaf, masker, botol steril, mikropipet, cawan petri, cotton bud steril, handscoon, tisu, hot plate, eppendorf tube, inkubator, jarum ose, kain kasa steril, kapas steril, lampu spiritus, dan Laminar Air Flow (LAF).

\section{Bahan Penelitian}

Bahan yang digunakan dalam penelitian ini adalah: Batang E. elatior dengan nomor determinasi 2100/IPH.I.01/If.07/VIII/2018, pelarut teknis $n$-heksana, etil asetat, etanol, $\mathrm{NaCl}$, media Mueller Hilton Agar, BHI (Brain Heart Infusion), media NA (Nutrient Agar), strain murni S. mutans

\subsection{Pembuatan Ekstrak Batang E. elatior}

Batang E. elatior yang digunakan adalah bagian batang sebanyak $15 \mathrm{~kg}$, kemudian disortir dan dicuci bersih dengan air mengalir untuk menghilangkan kotoran yang menempel, sampel kemudian dirajang lalu dijemur di bawah sinar matahari dengan ditutup kain hitam. Batang yang sudah kering dihaluskan, kemudian diekstraksi dengan metode maserasi bertingkat yang 
menggunakan 3 jenis pelarut yaitu $n$-heksana, etil asetat dan etanol.

Kemudian masing-masing ekstrak tersebut dipekatkan dengan rotary evaporator pada suhu $45^{\circ} \mathrm{C}$. Untuk pengujian antibakteri ekstrak batang E. elatior dibuat konsentrasi 20, 40,60, dan $80 \%$ dengan pelarut DMSO.

\subsection{Uji Fitokimia}

\section{Uji kandungan Flavonoid}

Sebanyak 0,5 g simplisia ditambahkan $25 \mathrm{~mL}$ air hangat, kemudian disaring. Filtrat $5 \mathrm{~mL}$ ditambahkan serbuk $\mathrm{Mg}$, dan beberapa tetes $\mathrm{HCl}$ $2 \mathrm{~N}$ dan $\mathrm{HCl}$ pekat. Jika terjadi perubahan warna menjadi merah, kuning atau jingga maka positif mengandung flavonoid [10].

\section{Uji Kandungan Alkaloid}

Sebanyak 0,5 g Simplisia batang E. Elatior dilarutkan ke dalam 20 tetes asam sulfat $2 \mathrm{~N}$, kemudian diuji menggunakan dua pereaksi alkaloid, yaitu: Mayer dan Wagner. Uji alkaloid positif jika terbentuk warna putih pada larutan yang ditambahkan pereaksi Mayer, dan endapan putih hingga jingga pada pereaksi Wagner [11].

\section{Uji Kandungan Saponin}

Sebanyak 0,5 g simplisia, dilarutkan dalam $10 \mathrm{~mL}$ akuades, dikocok selama 1 menit dalam tabung reaksi. Amati apakah timbul busa. Jika timbul busa, tambahkan beberapa tetes $\mathrm{HCl} 1 \%$ dan tunggu sampai 10 menit. Apabila busa stabil dalam kurun waktu tersebut maka ekstrak positif mengandung saponin [12].

\section{Uji Kandungan tanin}

Sebanyak $0,5 \mathrm{~g}$ simplisia dilarutkan dalam 10 $\mathrm{mL}$ air hangat. Kemudian dibagi ke dalam 2 tabung, lalu ditambahkan 2 tetes $\mathrm{FeCl}_{3} 0,1 \mathrm{~N}$. Jika terjadi perubahan warna menjadi biru hitam atau biru hijau menunjukkan adanya senyawa tanin dalam ekstrak [10].

\section{Uji kandungan steroid dan triterpenoid}

Sebanyak 0,5 g simplisia dilarutkan ke dalam $2 \mathrm{~mL}$ larutan kloroform, kemudian ditambahkan 10 tetes asetat anhidrat dan 3 tetes asam sulfat. Uji steroid dan triterpenoid dikatakan positif jika larutan yang dihasilkan membentuk warna merah atau ungu (triterpenoid) dan berubah menjadi biru atau hijau (steroid) [11].

\subsection{Uji Aktivitas Antibakteri Ekstrak Batang E. elatior}

Pembuatan Media Agar Miring

Sebanyak 9,25 g BHI dan 3,75 g Agar ditambahkan akuades hingga $250 \mathrm{~mL}$. Kemudian dididihkan dan diaduk hingga homogen. Media tersebut disterilkan dalam autoklaf pada suhu $121^{\circ} \mathrm{C}$ selama 15 menit, kemudian dibiarkan pada suhu ruangan selama \pm 30 menit sampai media memadat pada kemiringan $30^{\circ}$. Media agar miring digunakan untuk inokulasi bakteri [13].

\section{Inokulasi Bakteri pada Media Agar Miring}

Bakteri uji diambil dengan jarum ose steril, lalu ditanamkan pada media agar miring dengan cara menggores. Selanjutnya diinkubasi pada suhu $37^{\circ} \mathrm{C}$ selama 24 jam.

\section{Pembuatan Standar Kekeruhan Larutan (Larutan} Mc. Farland)

Larutan $\mathrm{H}_{2} \mathrm{SO}_{4} 0,36 \mathrm{~N}$ sebanyak $9,5 \mathrm{~mL}$ dicampurkan dengan larutan $\mathrm{BaCl}_{2} \cdot 2 \mathrm{H}_{2} \mathrm{O} 1,175 \%$ sebanyak $0,5 \mathrm{~mL}$ dalam erlenmeyer. Kemudian dikocok sampai terbentuk larutan yang keruh. Hasil kekeruhan digunakan sebagai standar kekeruhan suspensi bakteri uji.

\section{Pembuatan Suspensi Bakteri Uji}

Bakteri uji yang telah diinokulasi diambil dengan jarum ose steril lalu disuspensikan ke dalam tabung yang berisi $2 \mathrm{~mL}$ larutan $\mathrm{NaCl} 0,9 \%$ hingga diperoleh kekeruhan yang sama dengan standar kekeruhan larutan Mc. Farland. Perlakuan yang sama dilakukan pada setiap jenis bakteri uji.

Uji Aktivitas Antibakteri Dengan metode Difusi Sumuran

Suspensi bakteri S.mutans di swab pada media MHA, kemudian dibuat lubang sumuran menggunakan tabung yang diameternya disesuaikan seperti cakram disk. Kemudian dimasukan larutan uji yang berisi ekstrak batang E. elatior. Media MHA diinkubasi pada suhu $37^{\circ} \mathrm{C}$ selama 24 jam Diamati dan diukur diameter zona bening (clear zone) yang terbentuk di sekitar lubang dengan menggunakan penggaris/jangka sorong [14].

\section{Hasil dan Diskusi}

3.1 Hasil Uji Fitokimia

Uji fitokimia pada simplisia batang E. elatior dilakukan untuk mengetahui kandungan metabolit sekunder (Tabel 1). 
Tabel 1. Hasil Uji Fitokimia simplisia batang E. elatior.

\begin{tabular}{llcl}
\hline Golongan Senyawa & Hasil & Keterangan \\
\hline 1. & Flavonoid & + & Timbul warna kuning \\
2. & Saponin & + & Timbul busa \\
3. & Tanin & + & Warna hijau kehitaman \\
4. & Steroid & - & Tidak ada cincin hijau kehitaman \\
5. & Triterpenoid & + & Warna jingga \\
6. & Alkaloid (Wagner) & + & Endapan Coklat \\
\hline
\end{tabular}

Ket: (+) positif, (-) negatif

Tabel 2. Hasil Diameter Daya Hambat (DDH) Antibakteri Ekstrak Batang E. elatior Terhadap Bakteri S. mutans

\begin{tabular}{clcccc}
\hline \multirow{2}{*}{ No } & Sampel & \multicolumn{3}{c}{ Diameter Daya Hambat $(\mathbf{m m})$} & Rata-rata DDH \\
\cline { 3 - 4 } & & $\mathbf{I}$ & $\mathbf{I I}$ & $\mathbf{I I I}$ & \\
\hline 1 & Kontrol Positif & 14,00 & 18,00 & 17,33 & 16,44 \\
2 & Kontrol Negatif & 0,00 & 0,00 & 0,00 & 0,00 \\
& $n$-Heksana 20\% & 4,00 & 3,00 & 4,00 & 3,66 \\
\multirow{2}{*}{3} & $n$-Heksana 40\% & 5,33 & 4,00 & 2,00 & 3,77 \\
& $n$-Heksana 60\% & 3,33 & 6,00 & 2,33 & 3,88 \\
& $n$-Heksana 80\% & 5,00 & 4,66 & 4,00 & 4,55 \\
& Etil asetat 20\% & 21,00 & 15,00 & 15,66 & 17,22 \\
\multirow{2}{*}{4} & Etil asetat 40\% & 13,00 & 19,00 & 20,66 & 17,55 \\
& Etil asetat 60\% & 16,00 & 18,66 & 18,66 & 17,77 \\
& Etil asetat 80\% & 15,33 & 20,00 & 20,33 & 18,55 \\
& Etanol 20\% & 6,33 & 5,66 & 6,00 & 5,99 \\
\multirow{2}{*}{5} & Etanol 40\% & 7,00 & 7,33 & 7,00 & 7,11 \\
& Etanol 60\% & 8,00 & 7,00 & 7,33 & 7,44 \\
& Etanol 80\% & 8,33 & 8,00 & 7,33 & 7,88 \\
\hline
\end{tabular}

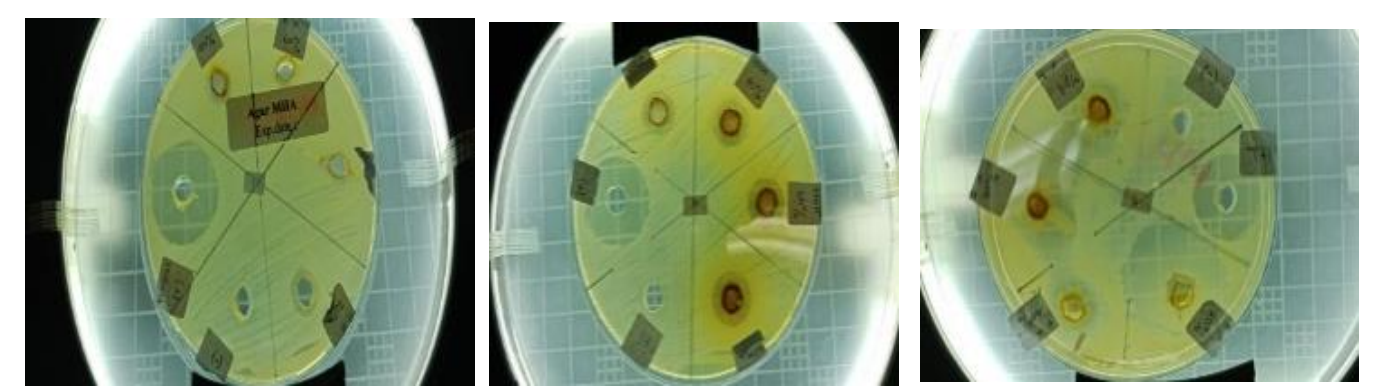

(a)

(b)

(c)

Gambar 1. Diameter daya hambat ekstrak: (a) n-heksana; (b) etanol, dan (c) etil asetat dari E. elatior terhadap bakteri S. mutans

Tabel 3. Kategori aktivitas antibakteri [15]

\begin{tabular}{cc}
\hline Diameter Daya Hambat $(\mathbf{m m})$ & Kategori \\
\hline$<5$ & Lemah \\
$5-10$ & Sedang \\
$10-20$ & Kuat \\
$>20$ & Sangat Kuat \\
\hline
\end{tabular}




\subsection{Hasil Pengujian Antibakteri}

Tabel 2 dan Gambar 1 adalah hasil pengujian antibakteri dari ekstrak E.elatior dari kontrol positif (Minosep), kontrol negatif (DMSO), konsentrasi ekstrak $n$-heksana, etil asetat dan etanol dengan konsentrasi 20, 40, 60 dan 80\%.

Proses ekstraksi simplisia batang E. elatior dilakukan dengan cara maserasi bertingkat dengan pelarut yang berbeda kepolaran. Sampel dimaserasi dengan pelarut $n$-heksana yang bersifat non polar adalah untuk menarik senyawa-senyawa yang bersifat non polar seperti minyak atsiri, lalu dengan etil asetat yang bersifat semi polar menarik senyawa semi polar, dan yang terakhir dimaserasi dengan etanol yang bersifat polar yang akan menarik senyawa-senyawa polar seperti golongan fenolik seperti flavonoid, saponin, tanin [16].

Pengujian antibakteri yang dilakukan dengan metode difusi sumuran. Aktivitas antibakteri ditentukan dengan mengukur zona hambat yang terbentuk di sekitar sumuran, yaitu berupa daerah bening yang tidak ditumbuhi bakteri pada media agar. Ekstrak yang yang digunakan untuk uji aktivitas antibakteri ialah ekstrak $n$-heksana, etil asetat dan etanol batang E. elatior dengan konsentrasi masing-masing 20, 40, 60 dan $80 \%$, kontrol positif (minosep) dan kontrol negatif (DMSO). Perbedaan konsentrasi dibuat untuk mengetahui tingkat efektivitas ekstrak menghambat pertumbuhan bakteri. Kontrol negatif yang digunakan adalah DMSO $100 \% \mathrm{~b} / \mathrm{v}$ [17]. DMSO merupakan salah satu pelarut sampel yang dapat melarutkan hampir semua senyawa baik polar maupun non-polar. Selain itu, DMSO tidak memberikan zona hambat terhadap pertumbuhan bakteri sehingga tidak mengganggu hasil pengamatan [5]. Kontrol positif yang digunakan ialah Minosep (klorheksidin), karena obat ini banyak digunakan untuk mengendalikan bakteri gigi dan mulut.

Pengujian esktrak $n$-heksana batang $E$. elatior menunjukkan bahwa semakin besar konsentrasi yang digunakan semakin besar zona hambat yang terbentuk. Zona hambat yang terbentuk pada konsentrasi 20, 40, 60, 80 dan $100 \%$ adalah masing-masing 3,66, 3,77, 3,88 dan $4,55 \mathrm{~mm}$. Konsentrasi ekstrak $n$-heksana batang $E$. elatior yang semakin meningkat memberikan zona hambat yang semakin besar, kemungkinan hal ini terjadi karena semakin banyaknya senyawa non polar yang terekstrak dapat mengganggu proses pertumbuhan bakteri S.mutans. Biasanya senyawa yang terdapat pada ekstrak nonpolar adalah trigliserida, asam lemak dan minyak atsiri [18].
Hasil pengujian ekstrak etil asetat batang $E$. elatior. terhadap bakteri $S$. mutans pada konsentrasi 20, 40, 60 dan 80\% didapat zona hambat sebesar 17,$22 ; 17,55 ; 17,77$ dan 18,55 $\mathrm{mm}$. Hal ini dikarenakan semakin tinggi konsentrasi semakin banyak kandungan bahan aktif antibakterinya. Keefektifan suatu zat antimikroba dalam menghambat pertumbuhan tergantung pada sifat mikroba uji, konsentrasi dan lamanya waktu kontak. Sifat biostatistik dapat meningkat dengan semakin tingginya konsentrasi yang ditambahkan [19]

Hasil pngujian ekstrak etanol E.elatior dengan konsentrasi 20, 40, 60, 80 dan 100\% adalah masing-masing 5,$99 ; 7,11 ; 7,44$ dan 7,88 $\mathrm{mm}$. Etanol salah satu jenis pelarut polar, sehingga senyawa bioaktif yang tersaring juga bersifat polar. Kepolaran senyawa yang tersaring inilah yang membuat senyawa bioaktif pada ekstrak etanol batang E. elatior dapat menembus dinding sel bakteri gram positif sehingga terlihat adanya diameter zona hambat pada bakteri S.mutans. Asam teikoat sebagai penyusun dinding sel bakteri gram positif merupakan polimer larut dalam air yang berfungsi sebagai transport ion positif untuk keluar dan masuk. Sifat larut air menunjukkan bahwa dinding sel bakteri Gram positif bersifat lebih polar, sehingga senyawa bioaktif yang bersifat polar dengan mudah masuk kedalam dinding sel dan merusak lapisan peptidoglikan yang bersifat polar dari pada lapisan lipid yang bersifat nonpolar [19].

Berdasarkan hasil penelitian, aktivitas antibakteri ekstrak $n$-heksana E. elatior termasuk kedalam kategori antibakteri lemah, ekstrak etil asetat dalam kategori kuat, dan ekstrak etanol dalam kategori sedang.

Berdasarkan hasil uji fitokimia (tabel 1), batang E. elatior mengandung metabolit sekunder alkaloid, flavonoid, saponin, tanin, dan triterpenoid. Metabolit sekunder tersebut diduga yang berperan dalam aktivitas antibakteri $S$. mutans pada tanaman E. elatior. Kemampuan senyawa alkaloid sebagai antibakteri $S$. mutans sangat dipengaruhi oleh keaktifan biologis senyawa tersebut. Senyawa alkaloid memanfaatkan sifat reaktif gugus basa pada senyawa alkaloid, adanya gugus basa pada alkaloid apabila megalami kontak dengan bakteri S. mutans akan bereaksi dengan asam amino yang menyusun dinding sel bakteri dan juga DNA bakteri yang merupakan penyusun utama inti sel yang merupakan pusat pengaturan segala kegiatan sel. Reaksi yang terjadi mengakibatkan terjadinya perubahan struktur dan susunan asam amino 
karena sebagian besar asam amino telah bereaksi dengan gugus basa dari senyawa alkaloid. Perubahan susunan asam amino akan mengubah susunan rantai DNA pada inti sel yang semula memiliki susunan asam dan basa yang saling berpasangan. Perubahan susunan rantai asam amino pada DNA akan menimbulkan perubahan keseimbangan genetik pada asam DNA sehingga DNA bakteri $S$. mutans akan mengalami kerusakan, dengan demikian bakteri S. mutans akan menjadi inaktif dan hancur [20].

Mekanisme kerja saponin sebagai antibakteri yaitu dapat mnyebabkan kebocoran protein dan enzim dari dalam sel [21]. Saponin dapat menjadi anti bakteri karena zat aktif permukaannya mirip detergen, akibatnya saponin akan menurunkan tegangan permukaan dinding sel bakteri dan merusak permebialitas membran. Rusaknya membran sel ini sangat mengganggu kelangsungan hidup bakteri. Saponin berdifusi melalui membran luar dan dinding sel yang rentan kemudian mengikat membran sitoplasma sehingga mengganggu dan mengurangi kestabilan membran sel. Hal ini menyebabkan sitoplasma bocor keluar dari sel yang mengakibatkan kematian sel [22].

Flavonoid merupakan turunan fenol yang dapat menyebabkan denaturasi dan koagulasi protein sel bakteri dimana senyawa flavonoid dalam merusak sel bakteri memanfaatkan perbedaan kepolaran antara lipid penyusun sel bakteri dengan gugus alkohol pada senyawa flavonoid. dilakukan dengan merusak dinding sel bakteri $S$. mutans yang terdiri atas lipid dan asam amino akan bereaksi dengan gugus alkohol pada senyawa flavonoid sehingga dinding akan rusak dan segera mengalami penguraian yang di ikuti penetrasi fenol ke dalam sel bakteri dan menyebabkan koagulasi protein sehingga membran sel bakteri mengalami lisis [20].

Mekanisme kerja antibakteri tanin mempunyai daya antibakteri dengan cara memprepitasi protein. Efek antibakteri tanin melalui reaksi dengan membran sel, inaktivasi enzim dan inaktivasi fungsi materi genetik. Mekanisme kerja tanin sebagai antibakteri adalah menghambat enzim reserse transiptase dan DNA topoisomerase sehingga sel bakteri tidak dapat terbentuk. Tanin memiliki aktivitas antibakteri yang berhubungan dengan kemampuannya untuk menginaktifkan adhesin sel mikroba, menginaktifkan enzim, dan mengganggu transport protein pada lapisan dalam sel. Tanin juga mempunyai target pada polipeptida dinding sel sehingga pembentukan dinding sel menjadi kurang sempurna. Hal ini menyebabkan sel bakteri menjadi lisis karena osmotik maupun fisik sehingga sel bakteri akan mati.

Mekanisme terpenoid sebagai antibakteri adalah bereaksi dengan porin (protein transmembran) pada membran luar dinding sel bakteri, membentuk ikatan polimer yang kuat sehingga mengakibatkan rusaknya porin. Rusaknya porin yang merupakan pintu keluar masuknya senyawa akan mengurangi permeabilitas dinding sel bakteri akan kekurangan nutrisi, sehingga pertumbuhan bakteri terhambat atau mati [23].

Mengacu pada standar umum yang dikeluarkan oleh Departemen Kesehatan (1998) disebutkan bahwa mikroba dinyatakan peka terhadap antimikroba asal tanaman apabila mempunyai ukuran diameter zona hambatnya 12$24 \mathrm{~mm}$. Hasil pengamatan tersebut menunjukkan bahwa ekstrak etil asetat batang E. elatior peka atau sensitif terhadap bakteri $S$. mutans dari konsentrasi 20 sampai $80 \%$ karena daya hambat yang dihasilkan sesuai dengan standar yang di tentukan oleh Departemen Kesehatan. Jika di bandingkan dengan kontrol positif, ekstrak etil asetat batang $E$. elatior memiliki daya hambat lebih tinggi dari kontrol positif (minosep)[24].

\section{Kesimpulan}

Ekstrak etil asetat batang E. elatior konsentrasi $20 \%$ memiliki aktivitas antibakteri kategori kuat yang sama dengan kontrol positif, dengan diamater zona hambat masing-masing 17,22 dan $16,44 \mathrm{~mm}$.

\section{Daftar Pustaka}

[1] Forssten SD, Björklund M, Ouwehand AC. Streptococcus mutans, Caries and Simulation Models. Nutrients. 2010. 2(3):290-8.

[2] Anastasia A, Yuliet Y, Tandah MR. MOUTHWASH FORMULATION OF TOOTH PLAQUE PREVENTING OF KAKAO (Theobroma cacao L) SEED EXTRACT AND EFFECTIVITY TEST ON Streptococcus mutans. J Farm Galen (Galenika J Pharmacy). 2017. 3(1):84.

[3] Zelnicek T. Streptococcus mutans Thoot Decay: Microbiology in Arezzo. Univ. of Oklahoma; 2014.

[4] Kusumawati E, Suprinigrum R, Rozadi R. Uji Aktivitas Antibakteri Ekstrak Etanol Daun Kecombrang Etlingera elatior (Jack) R. M. Sm Terhadap Salmonella typhi. FMIPA Univ Samarinda. 2015. 1(1):1-7. 
[5] Noncy FY, Pine TD, Hasnia A. Uji Aktivitas Antimikroba Hasil Fraksinasi Ekstrak Etanol Daun Patikala (Etlingera elatior) Terhadap Beberapa Mikroba Uji. JK FIK UINAM. 2016. 4(2):35-42.

[6] Naufalin R, Herastuti SR. Antibacterial activity of Nicolaia speciola fruit extract. IFJR. 2017. 24(1):379-85.

[7] Lachumy SJT, Sasidharan S, Sumathy V, Zuraini Z. Pharmacological activity, phytochemical analysis and toxicity of methanol extract of Etlingera elatior (torch ginger) flowers. Asian Pac J Trop Med. 2010. 3(10):769-74.

[8] Sukandar D, Radiastuti N, Jayanegara I, Hudaya A. Karakterisasi Senyawa Aktif Antibakteri Ekstrak Air Bunga Kecombrang (Etlingera elatior) Sebagai Bahan Pangan Fungsional. J Kim Val. 2010. 2(1).

[9] Chan E., Tan S, Lim Y. Standardised herbal extract of chlorogenic acid from leaves of Etlingera elatior (Zingiberaceae). Pharmacognosy Res. 2011. 3(3):178.

[10] Mangunwardoyo W, Cahyaningsih E, Usia T. Ekstraksi Dan Identifikasi Senyawa Antimikroba Herba Meniran (Phyllanthus niruri L.). J Ilmu Kefarmasian Indones. 2009. 7(2):57-63.

[11] Gustavina NLGWB, Dharma IGBS, Faiqoh E. Identifikasi Kandungan Senyawa Fitokimia Pada Daun dan Akar Lamun di Pantai Samuh Bali. J Mar Aquat Sci. 2017. 4(2):271.

[12] Karlina, C. Y., Ibrahim M, Trimulyono G. Aktivitas antibakteri ekstrak herba krokot (Portulaca oleracea L.) terhadap Staphylococcus aureus dan Escherichia coli. Lentera Bio. 2013. 2(1):87-93.

[13] Koswana S. Ekstrak Stroberi (Fragaria xananassa) terhadap Bakteri Streptococcus mutans dengan Metode Difusi Cakram. Karya Tulis Ilmiah, Akad Anal Farm dan Makanan Putra Indones Malang.

[14] Warsito W, Noorhamdani N, Sukardi S, Dwi Susanti R. MICROENCAPSULATION OF Cytrus hystrix OIL AND ITS ACTIVITY TEST AS AN ANTIMICROBIAL AGENT. $J$ Enviromental Eng Sustain Technol. 2017. 4(2):131-7.
[15] Davis WW, Stout TR. Disc Plate Method of Microbiological Antibiotic Assay. Appl Enviromental Microbiol. 2009. 22(44):666-70.

[16] Permadi A, Sutanto, Wardatun S. Perbandingan Metode Ekstraksi Bertingkat Dan Tidak Bertingkat Terhadap Flavonoid Total Herba Ciplukan (Physalis angulata L.) Secara Kolorimetri. Universitas Pakuan; 2015.

[17] Natheer F, Ismail Z, Mohamed N. Activities Of Extracts And Flavonoid Glycosides Of Corn Silk (Zea mays L.). Int J Biotecnol Wellnes Ind. 2012. 1(8765):115-21.

[18] Houghton PJ, Raman A. Laboratory Handbook for the Fractionation of Natural Extracts. Springer US; 1998.

[19] Ningtyas R. Uji Antioksidan Dan Antibakteri Ekstak Air Daun Kecombrang (Etlingera elatior (Jack)R. M. Smith) Sebagai Pengawet Alami Terhadap Escherchia coli Dan Staphylococcus aureus. UIN Syarif Hidayatullah; 2010.

[20] Mukti D. Uji Efektivitas Antibakteri Ekstrak Etanol Buah Pare (Momordica charantia L) Terhadap streptococcus mutans Penyebab Karies Gigi. Universitas Pakuan; 2012.

[21] Madduluri S, Rao KB, Sitaram B. In vitro Evaluation of Antibacterial Activity of Five Indegenous Plants Extract Againts Five Bacterial Pathogens of Human. Int J Pharm Pharm Sci. 2013. 5(4):679-84.

[22] Harbone JB. Metode Fitokimia Penuntun Cara Modern Menganalisis Tumbuhan. Terjemahan. Bandung: Institut Teknologi Bandung; 1987.

[23] Yaqin A. Potensi Antibakteri Ekstrak Etanol, Fraksi Etanol, Air dan Fraksi nHeksan Daun Anggur (Vitis vinifera L.) terhadap Staphylococcus aureus dan Pseudomonas aeruginosa Multiresisten. Universitas Muhammadiyah Surakarta; 2014.

[24] Depkes RI. Parameter Standar Umum ekstrak Tumbuhan Obat. Direktorat Jendral Pengawas Obat dan Makanan. 2006. 